\title{
Technology of Photovoltaic Conversion in Japan and Its Enlightenment for China
}

\author{
Wu Fan ${ }^{1, a}$ Chen Zhen ${ }^{2, a}$ \\ ${ }^{1}$ Beihua University,foreign language college, Beihua, Jilin 132013, China \\ ${ }^{2}$ Beihua University,fCollege of Information Technology and Media, Beihua, Jilin 132013, China \\ a59975235@qq.com
}

Key words: Japan; technology of photovoltaic conversion; efficiency; revelation

\begin{abstract}
As a country whose resources are deficient, Japan is being positive in exploring new energy and ahead of other countries. Electric power, as an important form of energy, is both primary energy consumption and secondary energy production industry, and Japan has made enormous efforts in new energy application in electric power industry. From the technology of photovoltaic conversion, the principle of technology of photovoltaic conversion and the current situation of its development in Japan are analyzed in this paper. The factors that affect the photovoltaic conversion efficiency are discussed and the ways that improve the photovoltaic conversion efficiency are proposed, which provide valuable experiences for the rapid development of photovoltaic industry in China.
\end{abstract}

\section{Introduction}

Since human being entered into industrial society, electric power has become the main primary energy consumption industry and the most important secondary energy production industry. Currently, electric power energy includes oil, natural gas, coal, water and other conventional energy, as well as new energy covering nuclear, solar, wind and biomass. Solar energy, as an inexhaustible supply of clean energy, has become a top priority of the world, which has driven the upsurge of photovoltaic power generation. According to statistical review of world energy 2011, at the end of 2010, the world's photovoltaic power installed capacity reached 39777 MW. Germany, which is the world's largest photovoltaic power country, the installed capacity in 2010 was $17320 \mathrm{MW}$, accounting for $43.5 \%$ of the world, while Japan ranked third place in the world after Germany and Spanish, the installed capacity was $3617 \mathrm{MW}$, took 9.1\% of the world share. This paper focused on the research and application oftechnology of photovoltaic conversion in Japan, and how to improve thephotovoltaic conversion efficiency to make a contribution to Japan's power energy. Meanwhile, combined with the current application ofthe photovoltaic conversion in Japan, we think about the enlightenment for the development of China's power resources.

\section{The present of technology of photovoltaic conversion and the principle analysis}

The solar cells used this effect are the devices made of semiconductor silicon, selenium and other materials, and they can absorb solar energy efficiently and convert it into electrical energy. These devices have the advantage of high reliability, long life, no pollution and high conversion efficiency, can be used as power source of artificial satellites, lanterns and transistor radios. The working principle is that sun light spreads on the PN junction and creates new pairs of electrons and holes. In the effect of PN junction electric field, holes flow from $\mathrm{N}$ to $\mathrm{P}$, while electrons flow from $\mathrm{P}$ to $\mathrm{N}$, which creates potential differences around PN junction and produces photovoltaic effect. When circuits connected, conversion from luminous energy to electrical energy is done. Single battery size is from $1 \times 1 \mathrm{~cm}$ to $15.6 \times 15.6 \mathrm{~cm}$ with several mill watts to watts of output power. Its theoretical conversion efficiency is over $25 \%$ while the practical efficiency is more than $22 \%$. Among many solar cells, there are four kinds of them who are common and practical; they are single crystal silicon, polycrystalline silicon, amorphous silicon, and multiple compound solar cells. 

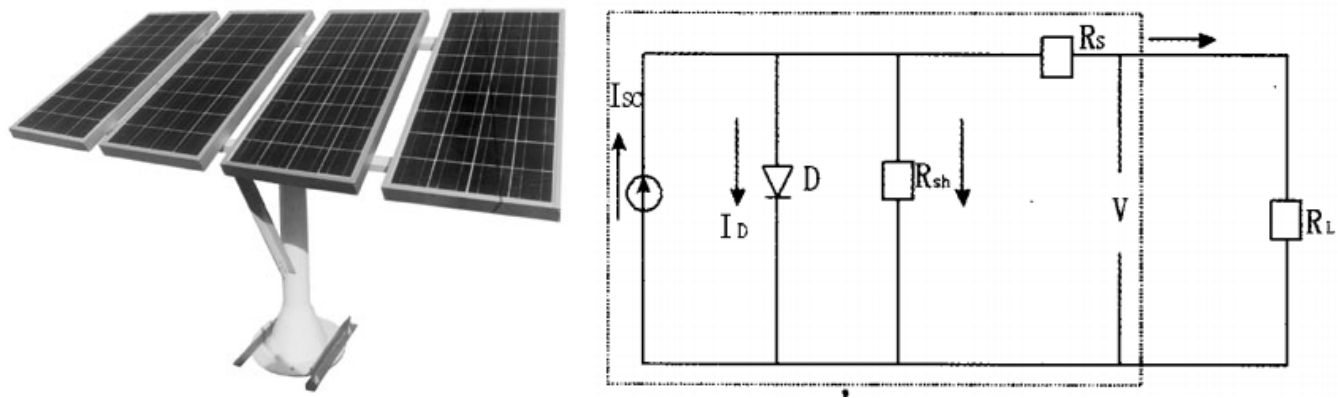

Picture 1 sketch map of common silicon solar cell Picture 2 electric current sketch map of ideal solar cells

\section{Current situation analysis of technology of photovoltaic conversion in Japan}

Solar energy is inexhaustible clean energy, sum of global energy consumption equivalent to only 40 minutes' energy projected from sun onto the earth's surface. According to Japanese experts, the energy produced by the sun is about 42 trillion kilocalories per second. Except a part is reflected into space, the rest is equal to 60 millions of one million $\mathrm{KW}$ nuclear power reactors operating at the same time. If this part of energy can be used as electrical energy, electric quantity in one hour is enough for all human beings for one year. Till 2013, solar power only account for $0.2 \%$ in Japanese energy structure. Under the severe energy situation, Japan has stepped up the research and development of large-scale photovoltaic equipments to improve the efficiency of solar cells, at the same time, Japan also constantly study new technology of solar cells and application styles.

Japanese Kyocera Corp recently started to produce a batch of the highest levels of polycrystalline solar modules whose photovoltaic conversion efficiency is $17.8 \%$, while the Panasonic Corp will use the new material and new structure of the battery modules in order to increase the photovoltaic conversion efficiency to 24\%. Thus, Japan has increased its strength on the research of solar cells in order to effectively improve photovoltaic conversion efficiency and had achieved good results.

Chart 1 Analytical statement on types and characteristics of solar cells in Japan

\begin{tabular}{|c|c|c|c|c|c|c|}
\hline types & $\begin{array}{l}\text { material } \\
\mathrm{s}\end{array}$ & structure & $\begin{array}{l}\text { measured } \\
\text { photovolta } \\
\text { ic } \\
\text { conversio } \\
\mathrm{n} \\
\text { efficiency( } \\
\%)\end{array}$ & $\begin{array}{l}\text { Cost } \\
\text { advan } \\
\text { tages }\end{array}$ & advantages & disadvantages \\
\hline \multirow[t]{3}{*}{ silicon } & $\begin{array}{l}\text { monocr } \\
\text { ystalline } \\
\text { silicon }\end{array}$ & $\begin{array}{l}\text { p type } \\
\text { monocrystalline } \\
\text { silicon layer with } \\
\mathrm{n} \text { type silicon } \\
\text { layers }\end{array}$ & 25.0 & poor & $\begin{array}{l}\text { high conversion } \\
\text { efficiency, high } \\
\text { reliability }\end{array}$ & $\begin{array}{l}\text { it' s not } \\
\text { appropriate for } \\
\text { scale production; } \\
\text { high costs; } \\
\text { conversion } \\
\text { efficiency close to } \\
\text { the limit }\end{array}$ \\
\hline & $\begin{array}{l}\text { polycrys } \\
\text { talline } \\
\text { silicon }\end{array}$ & $\begin{array}{l}\mathrm{p} \text { type } \\
\text { polycrystalline } \\
\text { silicon layer with } \\
\mathrm{n} \text { type silicon } \\
\text { layers }\end{array}$ & 20.4 & $\begin{array}{l}\text { gener } \\
\text { al }\end{array}$ & $\begin{array}{l}\text { lower cost } \\
\text { thanmonocrystall } \\
\text { ine silicon, } \\
\text { high conversion } \\
\text { efficiency, high } \\
\text { reliability }\end{array}$ & $\begin{array}{l}\text { conversion } \\
\text { efficiency is lower } \\
\text { than } \\
\text { monocrystalline } \\
\text { silicon; } \\
\text { uncertainty price } \\
\text { of raw material }\end{array}$ \\
\hline & $\begin{array}{l}\text { A-Si(am } \\
\text { orphous } \\
\text { silicon) }\end{array}$ & $\begin{array}{l}\text { product p, } \mathrm{i}, \mathrm{n} \\
\text { film with CVD } \\
\text { technology }\end{array}$ & 9.5 & $\begin{array}{l}\text { gener } \\
\text { al }\end{array}$ & $\begin{array}{l}\text { little silicon use } \\
\text { level; lower cost } \\
\text { than }\end{array}$ & $\begin{array}{l}\text { conversion } \\
\text { efficiency is lower } \\
\text { than }\end{array}$ \\
\hline
\end{tabular}




\begin{tabular}{|c|c|c|c|c|c|c|}
\hline & & & & & $\begin{array}{l}\text { monocrystalline } \\
\text { silicon }\end{array}$ & $\begin{array}{l}\text { monocrystalline } \\
\text { silicon; light leads } \\
\text { to ageing }\end{array}$ \\
\hline \multirow[t]{3}{*}{$\begin{array}{l}\text { compo } \\
\text { und }\end{array}$} & GaAs & $\begin{array}{ll}\text { organic } & \text { metal } \\
\text { vapor } & \text { phase } \\
\text { method } & \\
\end{array}$ & 26.1 & poor & $\begin{array}{l}\text { high efficiency, } \\
\text { good tolerance to } \\
\text { radiation in space }\end{array}$ & $\begin{array}{l}\text { low film-forming } \\
\text { rate; As is highly } \\
\text { toxic; high cost }\end{array}$ \\
\hline & CdTe & $\begin{array}{l}\mathrm{N} \text { type cadmium } \\
\text { sulfide with p } \\
\text { type CdTe } \\
\text { cadmium } \\
\text { telluride } \\
\text { polycrystalline } \\
\text { silicon }\end{array}$ & 16.7 & $\begin{array}{l}\text { gener } \\
\text { al }\end{array}$ & $\begin{array}{l}\text { varies } \\
\text { manufacture } \\
\text { methods; wave } \\
\text { band difference is } \\
\text { used to } \\
\text { generate;lower } \\
\text { cost than } \\
\text { monocrystalline } \\
\text { silicon }\end{array}$ & $\begin{array}{l}\text { Cd is toxic; rely } \\
\text { on Te }\end{array}$ \\
\hline & $\begin{array}{l}\text { CIS/CI } \\
\text { GS }\end{array}$ & $\begin{array}{l}\text { CIS/CIGS } \\
\text { plating air into } \\
\text { films }\end{array}$ & 19.4 & $\begin{array}{l}\text { gener } \\
\text { al }\end{array}$ & $\begin{array}{l}\text { high light } \\
\text { absorption rate }\end{array}$ & rely on $\mathrm{Te}$ \\
\hline $\begin{array}{l}\text { dye-se } \\
\text { nsitize } \\
\text { d }\end{array}$ & $\begin{array}{l}\text { pigment } \\
\text {, } \\
\text { semicon } \\
\text { ductor, } \\
\text { electroly } \\
\text { te }\end{array}$ & $\begin{array}{l}\text { put titanium } \\
\text { dioxide } \\
\text { electrodes into } \\
\text { electrolyte to } \\
\text { absorb pigment }\end{array}$ & 10.4 & better & $\begin{array}{l}\text { can be produced } \\
\text { in general air } \\
\text { condition; can be } \\
\text { colored or } \\
\text { hyalinized; can } \\
\text { be generated with } \\
\text { internal light }\end{array}$ & $\begin{array}{l}\text { ultraviolet rays } \\
\text { lead to ageing }\end{array}$ \\
\hline $\begin{array}{l}\text { Organi } \\
\text { c } \\
\text { thin-fil } \\
\mathrm{m}\end{array}$ & $\begin{array}{l}\text { fulleren } \\
\text { e, } \\
\text { polymer }\end{array}$ & $\begin{array}{l}\text { mix p type } \\
\text { polymer with } \mathrm{n} \\
\text { type fullerene to } \\
\text { coat }\end{array}$ & 5.2 & better & $\begin{array}{l}\text { can be produced } \\
\text { by the slimmest } \\
\text { and cheapest } \\
\text { spraying } \\
\text { technology }\end{array}$ & $\begin{array}{l}\text { ultraviolet rays } \\
\text { lead to ageing; } \\
\text { low conversion } \\
\text { efficiency }\end{array}$ \\
\hline
\end{tabular}

\section{The factors affect photovoltaic conversion efficiency}

\section{Light loss}

According to optical theory, when the light illuminate on the battery, the positive and negative side of the cells will have refraction and reflection effect, plus the blocking effect of electrodes and grid lines, therefore battery pieces cannot absorb all photons and short circuit current is decreased.

\section{Compound of pairs of electrons and holes}

The existence of compound affects electric current collection, and compound includes three kinds, they are internal compound, surface compound and depletion region compound. The internal compound is the major one.

\section{Loss in electric current transport}

The solar cells can be analyzed as a current source, like picture 2 .

In the picture, $\mathrm{D}$ refers to two-electrode valve, $R_{s h} 、 R_{S} 、 R_{L}$ separately indicate parallel resistance, series resistance and load. From equivalent circuit we can see that if the parallel resistance is small and the series resistance is large, then the output current is small, that is, the current has large loss in the output process. In practice, ideal solar cells do not exist, so we should consider the parallel and series resistances. When the load is short, $V=0$ now $I_{D}$ is very small, and the short circuit current can be expressed as:

$$
I_{S C}=\frac{I_{L}}{\left[1+R_{S} / R_{S h}\right]}
$$

According to (1) we can see that short circuit current $I_{S C}$ is connected with $R_{S} 、 R_{S h}$, when $V=0, I_{S C}$ is in direct proportion to area of the solar cells and irradiance of incident light. The 
expression of solar cells conversion efficiency is:

$$
\eta=\frac{P_{M}}{P_{\text {in }}}=\frac{I_{m} V_{m}}{P_{\text {in }}}=\frac{F F I_{S C} V_{O C}}{P_{\text {in }}}(2)
$$

In the above formula, $P_{\text {in }} 、 P_{\mathrm{m}} 、 F F 、 I_{S C} 、 V_{O C}$ separately represent solar incidence power, maximum output power, filling factor, short current and open circuit voltage. According to the expression, the greater the filling factor, the more helpful to improve conversion efficiency.

\section{The methods of improving photovoltaic conversion efficiency}

\section{The establishment and utilization of photovoltaic system}

Japan use two plastic lens structure of tatami-large area has the highest photovoltaic conversion efficiency in the world right now. The main principle is that a light panel of $7.2 \mathrm{~mm}$ area is set up in the lens. High intensity of sunlight is used to generate electric which makes the photovoltaic conversion efficiency up to $37.4 \%$ that is twice of general solar cells. At the same time, light panels can track the sun automatically; each piece of light panel can generate electric $800 \mathrm{w} . \mathrm{h}$, and only 8 tatami-large areas can provide a household of four people. And the key point of the high photovoltaic conversion efficiency is the use of the compound semiconductor material with 3 layers structure, which can absorb a greater wave length of light compare with single silicon cell panel. The establishment of photovoltaic system is to use the vacant space areas such as the roof of city apartments and public facilities or the space area that can get light in order to build a small power station for nearby residents.

\section{Research and development of high concentrator solar cells with wide spectrum}

Concentrator solar cells are battery pieces of multi-junction series based on GaAs, which has high photovoltaic conversion efficiency, good resistance ability to high temperature, small performance degradation after long working time little semiconductor material consumption, and covers 50\% area less than silicon. The key to improve the conversion efficiency is to improving material structure and increasing the concentration ratio. In order to solve the problems of cells material, the technology "quantum dot" was introduced. The optical absorption character of quantum dot depends on the size of quantum dot, which not only increases the absorption spectra of the solar light, but also reduces the internal stress caused by the lattice mismatch. Arakawa Yasuhiko, a professor at University of Tokyo, plans to use the new "quantum dots" technology, which can increase three times of the photovoltaic conversion efficiency compare with current situation. Through the computer calculation, he believes that the photovoltaic conversion efficiency of solar cells can reach $75 \%$ in theory, and the most practical conversion rate can be up to $60 \%$ according to conservative estimate, that is, from 2013, photovoltaic conversion efficiency can be increased 30\% within five years, and then within another five years it can reach $60 \%$.

To increase the solar cells concentration rate, an optical splitter can be used to reflect $98 \%$ of light from 400nm to $900 \mathrm{~nm}$ to the receiver, and then solar energy can be converted into electric, while the infrared light from $900 \mathrm{~nm}$ to $2.7 \mathrm{um}$ can heat working liquid directly through infrared window. The optical splitter with high performance and low cost will directly influence the use of hybrid solar receiver. If the reflector is processed a slight curved, it can further assemble the reflect light and the transmitted infrared light is divergent, which is not only good for photovoltaic conversion, but also good for the heating efficiency of the working liquid. The total energy of photo thermal conversion accounts more than $70 \%$ for utilization of solar energy. While in the concentration photovoltaic system, the cost of photovoltaic receiver is $35 \%$ of the total cost, and the concentrator system including lens, support and tracking mechanism covers $46 \%$, so the very important way to decrease cost is to improve the concentration system.

\section{The enlightenment for China's electrical generation industry}

Compared with the successful experience in the development of solar energy industry in Japan, China's current photovoltaic industry is still not getting rid of the essence of raw materials processing. The huge production capacity mainly concentrated in the steps of low cost of PV modules, and we didn't form a complete and mature industrial chain, so there is a lack of core 
technology competitiveness. Besides, $90 \%$ of the market is over the seas, and the development of the industry and the market is not balanced. Once the industrial policies in major consumer countries had adjustments, China's PV companies will face certain risks. What's more, some proper incentive and supportive policies from are still missing; refinement and implementation of these policies are still not in place, and protection and support of laws are not enough. In order to promote the steady and healthy development of solar energy industry in China, we should draw lessons from the successful experience of Japan's solar energy industry. (1) To complete incentive policies from the government and build photovoltaic technology research institutions; (2) To fully explore the potential of domestic market, in accordance with the long-term development of renewable energy planning, the total PV market is expected to $1800 \mathrm{MW}$ in 2020. (3) To create a complete industrial chain and improve the international competitiveness.

\section{Conclusion}

The photoelectric conversion technology in Japan is in the world's leading level, and changing the structure of the solar cell materials can continuously improve the photovoltaic conversion efficiency and make great contribution to the development of Japan's power resource. As one of the most rapidly developing economies in the world, China is only in the lower reaches of the world in technology and applications of photovoltaic power generation. In order to improve the development of China's solar energy industry effectively and promote the development of electric power resources, to create an industrial chain of mature, complete and with our own core technology is essential to focus.

\section{Acknowledgements}

This work is supported by the Project for Training Outstanding Youth of Jinlin.(Grant 20156412)

\section{References}

[1] Fan Liuyan, Qu delin(et al), The transformation of Japan's new energy pattern after the Fukushima nuclear crisis and its influence and Revelation[J].Sino-global energy, 2011,16(8): 29-33

[2] Xin Hua, A new technology of developing solar photovoltaic conversion rate in Japan,[J].Guangxi electric power, 2014(11): 79

[3] Negishi Hisami, The popularization of solar power generation system in Japan and the direction of expanding policies[R].Tokyo:Japan resources and energy department, 2010-09-12

[4] Guo Tingjie, New energy technology in the development of Japan[J].Shanxi energy and conservation, 2006(2): 8-9

[5] Feng Kuanhua,High concentrator solar cells with wide spectrum [A].National semiconductor devices industry development, innovative products and new technology seminar, 2011

[6] Chen Kailin, Ways to improve the photovoltaic conversion efficiency of solar cells [J].Scientific and technological information, 2013(1): 415,409

[7] Lv Zhi, The present situation of Japan's four big "ultimate" energy technology developments in 21 Century, [J].Global Science, Technology and Economy Outlook, 2013,28(7): 1-6,53

[8] Jia Xuping, SANYO produced high-efficient HIT solar cells, [J].Power supply technology, 2011,35(2): 127-129

[9] Liu Guangling, Jiang Qinlin(et al)Recent advances in research on improving the conversion efficiency of solar cells [J].Power supply technology, 2011.35(8): 1025-1027

[10]BaiduWenku,Goldman Sachs Research Report: international and domestic new energy industry [EB/OL].[2012-09-20]. http://wenku.baidu.com/view/b57fee02bed5b93f90f1c62.html 
[11]Liu Zhengxin. Solar cells[M].Beijing: Chemical Industry Press, 2010: 6

[12]Gao Liran.The developmental experience of solar energy industry in Japan and the enlightenment for China [J].Journal of Hebei Software Institute, 2014,16(1): 13-16,26 